\title{
Evaluation of the IS6 I I 0 PCR assay for the rapid diagnosis of tuberculous meningitis
}

\author{
Poonam S Deshpande ${ }^{1}$, Rajpal S Kashyap ${ }^{1}$, Sonali S Ramteke ${ }^{1}$, \\ Khushboo J Nagdev ${ }^{1}$, Hemant J Purohit ${ }^{2}$, Girdhar M Taori ${ }^{1}$ and \\ Hatim F Daginawala*1
} \author{
Unit, National Enviromental Engineering Research Institute, Nehru Marg, Nagpur, India, 440020 \\ Email: Poonam S Deshpande - poonamkd@gmail.com; Rajpal S Kashyap - raj_ciims@rediffmail.com; \\ Sonali S Ramteke - sonaliramteke8@yahoo.co.in; Khushboo J Nagdev - khushbu.nagdev@gmail.com; \\ Hemant J Purohit - hemantdrd@hotmail.com; Girdhar M Taori - taorigm_ciims@yahoo.co.in; \\ Hatim F Daginawala* - hfd_ciims@rediffmail.com \\ * Corresponding author
}

Address: ${ }^{1}$ Biochemistry Research Laboratory, Central India Institute of Medical Sciences, Nagpur, India, 440010 and ${ }^{2}$ Environmental Genomics

Published: 2 November 2007

Cerebrospinal Fluid Research 2007, 4:10 doi:10.1 186/1743-8454-4-10
Received: 26 May 2007

Accepted: 2 November 2007

This article is available from: http://www.cerebrospinalfluidresearch.com/content/4/I/10

(C) 2007 Deshpande et al; licensee BioMed Central Ltd.

This is an Open Access article distributed under the terms of the Creative Commons Attribution License (http://creativecommons.org/licenses/by/2.0), which permits unrestricted use, distribution, and reproduction in any medium, provided the original work is properly cited.

\begin{abstract}
Background: Tuberculous meningitis (TBM) is one of the common clinical manifestations of extra-pulmonary tuberculosis. It is difficult to diagnose due to a lack of rapid, sensitive, and specific tests. Newer methods, which are easy and reliable, are required to diagnose TBM at an early stage. Thus our aim was to evaluate the polymerase chain reaction (PCR) technique, using primers directed against the IS6II 0 gene, for the detection of Mycobacterium tuberculosis in the CSF, for the diagnosis of TBM patients.

Methods: An in-house IS6 I 10 PCR method using a specific pair of primers designed to amplify the insertion sequence, IS6 IIO, in the M. tuberculosis genome was used to analyze CSF. A total of 80 CSF samples from different groups of patients were studied (confirmed TBM $n=35$, clinically suspected TBM $n=16$, non-TBM infectious meningitis $n=12$, non infectious neurological diseases $\mathrm{n}=17)$.

Results: PCR gave a sensitivity of $91.4 \%$ and specificity of $75.9 \%$ for the diagnosis of TBM in patients with TBM confirmed by culture. In 16 clinically diagnosed, but unconfirmed, TBM cases PCR was positive in $10(62.5 \%)$ cases. There were seven (24. I\%) PCR-positive cases among the 29 patients with non-TBM and non-infectious neurological disease.
\end{abstract}

Conclusion: We conclude that the performance of an in-house IS6/10 PCR assay is valuable in the rapid diagnosis of tuberculous meningitis.

\section{Background}

Tuberculosis (TB) is one of the major causes of morbidity and mortality worldwide. India has about 1.8 million new cases of TB annually, accounting for a fifth of new cases in the world - a greater number than in any other country [1]. Among, extra-pulmonary TB, tuberculous meningitis (TBM) leads to multiple central nervous system (CNS) complications and remains a major health problem in 
underdeveloped and developing countries [2]. Delayed treatment of TBM is associated with high mortality and with neurological problems, which underscores the importance for early diagnosis [3].

Confirming the clinical suspicion of TBM has always been problematic. Acid-fast bacilli (AFB) staining of cerebrospinal fluid (CSF) has a very low sensitivity [4]. Although conventional bacterial culture is the gold standard for diagnosis, the inherent time limitation of the culturebased test, limits its value $[5,6]$. The culture of $M$. tuberculosis from CSF takes 4-6 weeks and leads to a delay in diagnosis $[7,8]$. Analysis of CSF using antibody detection is suggestive but not diagnostic of TBM [9]. In the absence of any reliable diagnostic methods, various immunological and molecular methods have been advocated including ELISA [10] for demonstration of M. tuberculosis antigen and antibodies, $\mathrm{T}$ cell based assay for IFN gamma estimation (ELI SPOT), adenosine deaminase assay $[11,12]$, and polymerase chain reaction (PCR) $[13,14]$. However, all the above-mentioned methods are still being evaluated.

Rapid techniques based on nucleic acid amplification such asPCR have been reported to be more sensitive and specific as they attempt to detect specific DNA sequences from the organism under investigation. Several M. tuberculosis specific DNA sequences have been evaluated in different laboratories including MBP-64, 65 kDa antigen and IS6110 [14]. The reliability of PCR depends on the amplification of DNA with primers specific for different target sequences in the mycobacterial genome, and on optimal DNA isolation and PCR procedures [15]. The observed sensitivity and specificity of the PCR for M. tuberculosis in clinical samples differs greatly among the different laboratories ranging from $50-90 \%$ and $60-100 \%$, respectively [6]. The repetitive nature of IS6110 insertion sequence in $M$. tuberculosis genome makes it an attractive target for PCR amplification, as it could contribute to a higher degree of sensitivity of the assay $[16,17]$. Several studies have been undertaken to evaluate the efficacy of IS6110 sequence for the diagnosis of tuberculosis $[5,8,14]$. In our study, we describe our experience with the IS6110 based PCR assay to detect $M$. tuberculosis DNA in CSF samples of TBM and non-TBM cases in our Institute.

\section{Methods}

CSF samples from a total of 80 patients were analysed. These consisted of confirmed and clinically suspected TBM patients, $\mathrm{n}=51$, patients with other infections (pyogenic meningitis, $\mathrm{n}=5$, viral meningitis, $\mathrm{n}=7$ ), and control subjects with non-infectious neurological disorders, $\mathrm{n}$ $=17$. Patients for this study were admitted to the Neurology Department of Central India Institute of Medical sciences (CIIMS), Nagpur between September 2005 and
December 2006. All patients were above the age of 20 years and had given written consent for the study. CSF samples for ADA estimations and other tests were obtained before starting any specific treatment in all cases of neurological disorders including viral, bacterial, and mycobacterial meningitis. The Institutional Ethics Committee of Central India Institute of Medical Sciences, Nagpur, approved the study. To establish a diagnosis of meningitis, 2-5 $\mathrm{ml}$ of CSF was withdrawn from patients using a lumbar puncture. CSF was then subjected to routine biochemical and pathological analysis including Gram, India ink, and AFB staining and culturing. Diagnosis of TBM and non-TBM was based on criteria described below.

\section{Patient groups}

I. Tuberculous meningitis patients $(n=5 I)$

A: Clinically confirmed cases $(\mathrm{n}=35)$ : Confirmed by the presence of M. tuberculosis in CSF by staining and/or culture.

B: Clinically suspected patients ( $n=16$ ): This group had negative cultures with all of the following observations:

a: Sub-acute or chronic fever with features of meningeal irritation such as headache, neck stiffness and vomiting, with or without other features of CNS involvement.

b: CSF samples showing raised protein levels, and/or decreased glucose (CSF: blood glucose ratio $<0.5$ ), and/or pleocytosis with lymphocytic predominance.

c: Good clinical response to anti-tuberculous drugs.

\section{Non-TBM patients}

A) Non-TBM infectious meningitis $(n=12)$

A: Pyogenic meningitis $(n=5)$ :

Confirmed cases $(n=2)$ : Presence of pathogenic bacteria in CSF by staining and/or culture.

Clinically suspected ( $\mathrm{n}=3$ ): This group included the culture negative cases with all of the following observations:

a: Fever and/or signs of meningeal irritation (patients who have undergone cranial surgery to treat tumor(s), stroke, or head injury and who have received antibiotics), or high fever and/or signs of meningeal irritation with or without CNS manifestations (patients who received broad-spectrum antibiotics).

b: CSF findings showing increased proteins, decreased glucose (CSF: blood glucose ratio $<0.2$ ), and/or pleocytosis with a predominance of polymorphonuclear cells. 
c: Good clinical response to road-spectrum antibiotics.

B: Viral meningitis patients $(n=7)$ : This group included suspected patients with the following observations:

a: Acute onset of fever and symptoms and signs of meningeal irritation.

b: CSF samples showing mild increase in protein, glucose levels often normal, and pleocytosis, predominantly lymphocytic.

c: No clinical evidence for extra cranial tuberculosis.

B) Non-infectious neurological disorders group $(n=17)$

All other patients who had no evidence of CNS or extra CNS bacterial or viral infections were grouped in the noninfectious/control group. Patients included in this group had chronic headache and hypertension $\mathrm{n}=10$, head injury $n=2$, paraparesis, dementia, myelopathy, acute cerebellitis, and epilepsy, $\mathrm{n}=1$ each.

\section{Culture procedure}

CSF samples $(0.5 \mathrm{ml})$ were inoculated into $5 \mathrm{ml}$ BioFM liquid media (Biorad, Marnes-la-Coquette, France) and incubated at $37^{\circ} \mathrm{C}$. All culture samples were examined twice a week for 6 weeks. The positivity of culture was defined by the growth of mycobacteria in the liquid media.

\section{DNA extraction}

DNA was extracted according to the CTAB-phenol chloroform extraction method. Briefly, $0.2 \mathrm{ml}$ of CSF was centrifuged at 10,000 rpm for $10 \mathrm{~min}$. The supernatant was discarded and the pellet suspended in $567 \mu \mathrm{l}$ of TE buffer (Tris EDTA, pH 7.4), $30 \mu \mathrm{l} 10 \%$ SDS and $3 \mu$ proteinase $\mathrm{K}(20 \mathrm{mg} / \mathrm{ml})$, mixed and incubated at $37^{\circ} \mathrm{C}$ for $1 \mathrm{~h}$. After incubation, $100 \mu \mathrm{l}$ of $5 \mathrm{M} \mathrm{NaCl}$ and $80 \mu \mathrm{l}$ of high-salt CTAB buffer (containing $4 \mathrm{M} \mathrm{NaCl}, 1.8 \%$ CTAB (cetyl-trimethyl-ammonium bromide) was added and mixed followed by incubation at $65^{\circ} \mathrm{C}$ for $10 \mathrm{~min}$. An approximate equal volume $(0.7-0.8 \mu \mathrm{l})$ of chloroform-isoamyl alcohol (24:1) was added, mixed thoroughly and centrifuged for 4-5 min in a microcentrifuge at $12,000 \mathrm{rpm}$. The aqueous viscous supernatant was carefully decanted and transferred to a new tube. An equal volume of phenol: chloroform-isoamyl alcohol (1:1) was added followed by a 5 min spin at 12,000 rpm. The supernatant was separated and then mixed with 0.6 volume of isopropanol to get a precipitate. The precipitated nucleic acids were washed with $75 \%$ ethanol, dried and re-suspended in $100 \mu \mathrm{l}$ of TE buffer.

\section{Polymerase chain reaction (PCR)}

In each independent PCR assay, test results were compared with the results for one positive and one negative control. The positive controls included the DNA of $\mathrm{H}_{37} \mathrm{Rv}$ strain provided by Colorado State University, Fort Collins, USA, (Contract No 1-A1-40091). Negative control included PCR grade water.

Identification of $M$. tuberculosis was done using a specific pair of primers designed to amplify an insertion sequence IS6110 in the M. tuberculosis complex and the expected band size was about123-bp. The sequence of these primers, T4 and T5, are: 5'-CCT GCG AGC GTA GGC GTC GG 3' and 5' CTC GTC CAG CGC CGC TTC GG 3' respectively. A $50 \mu$ reaction contained $10 \times$ assay buffer (Bangalore Genei, Bangalore, India), $10 \mathrm{mM}$ dNTP's (Bangalore Genei), 10 pmole of each primer (SIGMA-GENOSYS, USA), 2.5 units Taq DNA Polymerase (Bangalore Genei) and $5 \mu \mathrm{l}$ of extracted DNA. Amplification was carried out in a thermal minicycler (peqlab Biotechnologie $\mathrm{GmbH}$, Erlangen, Germany), which involved 40 cycles of denaturation at $94^{\circ} \mathrm{C}$ for $2 \mathrm{~min}$, annealing of primers at $68^{\circ} \mathrm{C}$ for $2 \mathrm{~min}$, and primer extension at $72^{\circ} \mathrm{C}$ for $1 \mathrm{~min}$. The amplification products were separated on $2 \%$ agarose gels, visualized on a UV- light transilluminator (Biotech R \& D Laboratories, Yercud, Salem, India) and photographed.

\section{Results}

Figure 1 shows the electrophoresis product of the $123 \mathrm{bp}$ amplification of IS6110 sequence of $M$. tuberculosis by

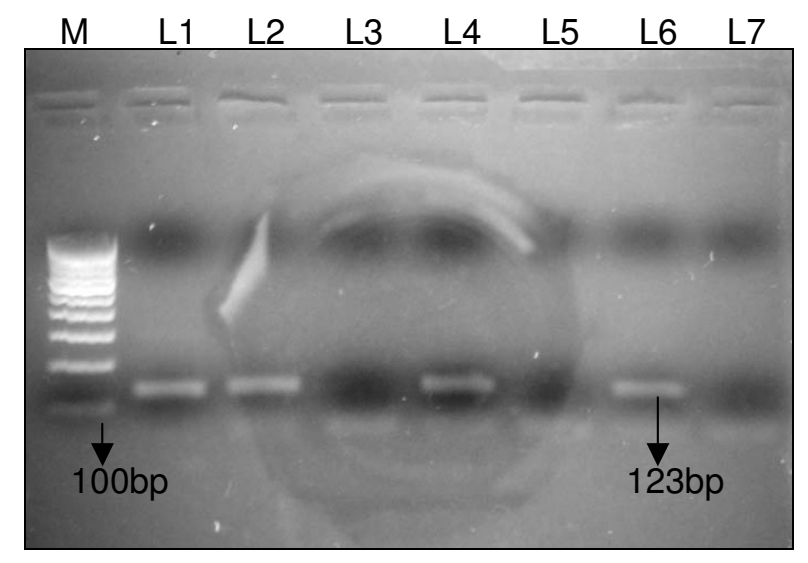

\section{Figure I}

Amplification of the 123 bp product of $M$. tuberculosis by PCR. PCR products were analyzed by electrophoresis on $2 \%$ agarose gel. $M$ represents 100 bp DNA ladder. LI: positive control DNA (M. tuberculosis strain $\mathrm{H}_{37} \mathrm{Rv}$ ). L2, L4, L6: clinically positive TBM samples. L3, L5: non-TBM samples. L7: negative control. 
PCR. M represents 100 bp DNA ladder. Lane 1 (L1) represents the positive control DNA (M. tuberculosis strain $\mathrm{H}_{37} \mathrm{Rv}$ ). L2, L4, L6 show clinically positive TBM samples, and L3 and L5 represent non-TBM samples. L7 is a negative control.

The results of the IS6110 PCR assay in the TBM and nonTBM CSF samples are shown in Table 1. The IS6110 PCR assay was positive in $91.4 \%$ (32/35) of confirmed TBM cases. However, in the clinically diagnosed TBM patients, but not confirmed by culture, the sensitivity of IS6110 PCR assay was 62.5\% (10/16) (Table 1). Using culture as the gold standard, the PCR assay showed a sensitivity of $91.4 \%$ and specificity of $75.9 \%$ with a positive predictive value $(\mathrm{PPV})=85.7 \%$ and negative predictive value $(\mathrm{NPV})$ $=71.9 \%$ ). The overall sensitivity and specificity (including the TBM confirmed and clinically suspected cases together) of PCR was thus found to be $82.4 \%$ (NPV = $71.9 \%)$ and $75.9 \%(\mathrm{PPV}=85.7 \%)$ respectively.

In the non-TBM infectious control group, PCR was positive in 3 samples ( 2 viral meningitis and 1 pyogenic meningitis). In non-infectious control group PCR was found to be positive in 4 samples ( 2 chronic headache, and 1 each of epilepsy and acute inflammatory demyelinating myelitis, Table 1).

We have also compared our PCR data with the culture results, which showed a sensitivity of $68.6 \%$ (NPV = $79.3 \%)$ and a specificity of 79.3\% (PPV $=85.3 \%)$ as compared to PCR showing $82.4 \%$ sensitivity $(\mathrm{NPV}=71 \%)$ and 75.9\% specificity $(\mathrm{PPV}=85.7 \%)$, (Table 2$)$.

\section{Discussion}

TBM is one of the common clinical manifestations of extra-pulmonary tuberculosis. There has been a rising trend of TBM in developing countries like India in the past two decades. The detection of TBM is difficult to establish because of its pleomorphic clinical presentation and vari-

Table I: Numbers and percentages of patients showing positive or negative PCR in CSF samples.

\begin{tabular}{lcc}
\hline Category & PCR +ve & PCR -ve \\
\hline $\begin{array}{l}\text { A] TBM (5I) } \\
\text { (i) Confirmed TBM * (35) } \\
\text { (ii) Clinically diagnosed TBM ** (16) }\end{array}$ & $42(82.4 \%)$ & \\
\hline & $32(91.4 \%)$ & 3 \\
B] Non TBM (29) & $7(22.5 \%)$ & 6 \\
(i) Infectious \# (12) & $3(25.1 \%)$ & \\
(ii) Non-infectious\# (17) & $4(23.5 \%)$ & 13
\end{tabular}

*Confirmed TBM = culture +ve/smear -ve

** Clinical diagnosed TBM = culture -ve/smear - ve

\#Pyogenic meningitis (5), viral meningitis (7)

\# Chronic headache \& hypertension (10), head injury (3), paraparesis,

dementia, myelopathy, acute cerebellitis ( $I$ each) able CSF cellular content and biochemical parameters, similar to that of partially treated pyogenic meningitis cases. Delayed diagnosis and treatment may be associated with many serious CNS complications [18]. Hence, rapid detection of $M$. tuberculosis is of vital importance for the proper diagnosis and management of tuberculous meningitis. Polymerase chain reaction is considered to be one of the most specific diagnostic methods amid the many rapid methods studied. PCR is the method of choice for the diagnosis of tuberculosis in cases where the suspicion is high but AFB staining is negative [19]. Many investigators have described the rapid detection of $M$. tuberculosis by PCR, and have reported a high degree of sensitivity using this method [20-24]. Although, IS6110 PCR is not a novel diagnostic tool, it is believed that more studies are required to establish its utility in the diagnosis of TBM [20]. This study was planned to evaluate the efficacy of an in-house IS6110 PCR assay to detect M. tuberculosis DNA in CSF samples collected in our Institute.

The characteristic of the IS6110 PCR assay is that it should be capable of detecting the presence of $M$. tuberculosis DNA in all the samples proven to be TBM positive using culture as the gold standard [20]. The present study was performed blinded to evaluate the IS6110 PCR assay for detection of $M$. tuberculosis in CSF samples available from our hospital, using an in-house protocol. In our study, the IS6110 PCR assay detected the presence of $M$. tuberculosis DNA in $91.4 \%(32 / 35)$ cases of confirmed TBM and in $62.5 \%(10 / 16)$ cases of clinically diagnosed TBM which were negative for mycobacterial culture, but had a clinical index of suspicion for TBM.

Our results show agreement with some previous studies, which showed $85-98 \%$ sensitivity $[20,25,26]$ and a disparity to various other studies, which had a low sensitivity of 32-75\% [27-30]. Rafi etal used a DNA extraction protocol involving CTAB detergent, which enhances PCR positivity in CSF samples [20]. We have also used the same detergent along with the phenol-chloroform method for DNA extraction. The reason for lower sensitivity in many studies is unclear. However, it could be due to the low volume of CSF available, inefficient lysis of cells and/or loss of DNA during purification or different methods used for extraction of DNA [6]. In our study, the reason for PCR negativity in six out of 16 clinically diagnosed TBM cases could be the presence of a low number of bacteria or poor lysis of bacteria, or possibly the presence of some PCR inhibitors like bacterial contaminants, phenol etc. in the CSF samples. Sometimes the tough cell wall of M. tuberculosis makes the isolation of target DNA difficult [30]. There have been a few reports citing the existence of mycobacterial strains that lack IS6110 element and therefore, infection with an IS6110 negative strain cannot be ruled out [30-33]. Other sequences such as Ag85, MPB-64, 65 kDa, 
Table 2: Sensitivity and specificity of PCR test compared to CSF culture.

\begin{tabular}{|c|c|c|c|c|c|c|}
\hline \multirow{2}{*}{$\begin{array}{c}\text { Test Result } \\
\text { PCR }\end{array}$} & \multicolumn{2}{|c|}{ Final Diagnosis } & \multirow[t]{2}{*}{ Sensitivity } & \multirow[t]{2}{*}{ Specificity } & \multirow[t]{2}{*}{ PPV } & \multirow[t]{2}{*}{ NPV } \\
\hline & TBM $(N=51)$ & $\underset{29)}{\text { Non TBM }(N=}$ & & & & \\
\hline Positive & 42 & 07 & $82.4 \%$ & $75.9 \%$ & $85.7 \%$ & $71 \%$ \\
\hline Negative & 09 & 22 & & & & \\
\hline \multicolumn{7}{|l|}{ Culture } \\
\hline Positive & 35 & 06 & $68.6 \%$ & $79.3 \%$ & $85.3 \%$ & $79.3 \%$ \\
\hline Negative & 16 & 23 & & & & \\
\hline
\end{tabular}

and $38 \mathrm{kDa}$ have also been used as target for PCR amplification. But IS6110 PCR has shown enhanced sensitivity and specificity as a single step PCR assay [14,34]. Nested PCR assay for diagnosis of TBM has provided a considerable increase in sensitivity and specificity of DNA amplification compared to conventional single-step PCR assay $[35,36]$. However, the nested PCR assay using CSF samples has yet to be widely used in TBM diagnosis, due to its laborious and time-consuming procedure, which carries a high risk of sample contamination [36,37].

For the detection of overall TBM cases, the IS6110 PCR assay was useful in terms of sensitivity (82.4\%) and specificity $(75.9 \%)$ as compared to culture results showing $68.6 \%$ sensitivity and $79.3 \%$ specificity in overall TBM and non-TBM cases (Table 2). Therefore, it has been found that IS6110 PCR is a good supportive method for rapid diagnosis of clinically diagnosed TBM, particularly where AFB staining and cultures are negative. Some other studies have also suggested that CSF PCR for M. tuberculosis is more sensitive than AFB staining and culture in cases of clinically suspected TBM that responded to empirical treatment [38].

Although the PCR can amplify the specific DNA sequence by thousands of times within a few hours, the exquisite specificity of PCR is also its main potential drawback. Out of 29 non-TBM cases, PCR was positive in 3 cases of infectious group ( 1 for pyogenic meningitis and 2 for viral meningitis). In our study, the two PCR positive cases of viral meningitis also had a positive TB culture, which suggests they could be classified as case of mixed meningitis. Mixed bacterial meningitis involving mycobacteria and other bacteria have also been described earlier [39].

PCR was also positive in four cases of non-infectious nonTBM group, which were actually diagnosed for chronic headache (two cases), epilepsy and myelopathy myelitis (one each). One reason for such false positive results could be cross contamination with the amplified DNA product in the laboratory. This is a well-recognized prob- lem in other laboratories [40]. In spite of a small number of CSF samples showing a positive result in the control groups, the PCR assay was allied with a specificity of $75.9 \%$.

Despite the improved sensitivity and specificity of PCR technique, AFB and culture remain an important technique for diagnosing TBM. In this study, if the PCR method had been accepted as the only diagnostic criteria, it would have missed three culture confirmed cases.

In a meta-analysis of in-house and commercial protocols used in the diagnosis of TBM, the results revealed that commercial tests had an increased specificity but low sensitivity $(56 \%)$. This was in stark comparison to the substantial variability of the test results seen whenever an inhouse protocol was used [41]. Also the high cost involved for commercial assays make it a significant drawback, especially in developing countries like India. In such settings, the role of an in-house assay turns out to be useful in aiding the clinician towards a diagnosis of TBM, with a reliable degree of specificity and sensitivity.

\section{Conclusion}

Our study made it evident that in-house IS6110 PCR is a rapid and cost-effective diagnostic test for TBM that shows good sensitivity and specificity. This can be adopted as a method of choice for the diagnosis of mycobacterial infections in cases where suspicion is high, in combination with other clinical criteria.

\section{Competing interests}

The author(s) declare that they have no competing interests.

\section{Authors' contributions}

PSD carried out the study design, data collection, data interpretation, literature search, and manuscript preparation; RSK and HJP participated in the preparation of the manuscript, data interpretation, and study design; SSR and KJN contributed in collection of samples and data 
interpretation, GMT provided assistance in preparation of the manuscript, data interpretation, study design, and funds collection; and HFD supervised the study design, data interpretation and manuscript preparation. All authors have read and approved the final version of the manuscript.

\section{Acknowledgements}

We would like to acknowledge the help of Colorado State University, Fort Collins, USA for supplying M. tuberculosis $\mathrm{H}_{37} \mathrm{Rv}$ DNA (Contract No I-AI40091).

\section{References}

I. Steinbrook R: Tuberculosis and HIV in India. New Eng J Med 2007, 356: I 198-11 99

2. Kashyap RS, Kainthla RP, Satpute RM, Agarwal NP, Chandak NH, Purohit HJ, Taori GM, Daginawala HF: Differential diagnosis of tuberculous meningitis from partially treated pyogenic meningitis by cell ELISA. BMC Neurology 2004, 4:16.

3. Baker CA, Cartwright CP, Williams DN, Nelson SM, Peterson PK: Early detection of central Nervous System Tuberculosis with the Gene-Probe Nucleic Acid amplification Assay: Utility in an Inner city hospital. Clin Infec Di 2002, 35:339-342.

4. Bonington AJl, Strang G, Klapper PE: Use of Roche AMPLICOR Mycobacterium tuberculosis PCR in Early Diagnosis of Tuberculous Meningitis. J Clin Microbiol 1998, 36: | 25 I-I 254.

5. Kulkarni SP, Jaleel MA, Kadival GV: Evaluation of an in-housedeveloped PCR for the diagnosis of tuberculous meningitis in Indian children. J Med Microbiol 2005, 54:369-373.

6. Noordohek GT, Kolk AHJ: Sensitivity and Specificity of PCR for Detection of Mycobacterium tuberculosis: a Blind Comparison Study among Seven Laboratories. J Clin Microbiol 1994, 32:277-284.

7. Sumi MG, Mathai A, Reuben S, Sarada C, Radhakrishnan VV: Immunocytochemical Method for Early Laboratory Diagnosis of Tuberculous Meningitis. Clin Diagn Lab Immunol 2002, 9:344-347.

8. Caws M, Wilson SM, Clough C, Drobniewski F: Role of IS6 I I 0-Targeted PCR, Culture, Biochemical, Clinical, and Immunological Criteria for Diagnosis of Tuberculous Meningitis. Clin Microbiol 2000, 38:3I50-3I55.

9. Chandramuki A, Lyashchenko K, Kumari HBV, Khanna N, Brusasca PN, Gourie-Devi M, Satishchandra P, Shankar SK, Ravi V, Alcabes P, Kanaujia GV, Gennaro ML: Detection of Antibody to Mycobacterium tuberculosis Protein Antigens in the Cerebrospinal Fluid of Patients with Tuberculous Meningitis. J Infect Dis 2002, 186:678-683.

10. Kashyap RS, Kainthla RP, Satpute RM, Chandak NH, Purohit HJ, Taori GM, Daginawala HF: Demonstration of IgG antibodies to $30 \mathrm{Kd}$ protein antigen in CSF for diagnosis of tuberculous meningitis by antibody-capturing ELISA. Neurol Ind 2004, 52:359-362.

11. Prasad R, Kumar A, Khanna BK, Mukerji PK, Agarwal SK, Kumar A, Srivastava VM: Adenosine deaminase activity in CSF for diagnosis of tuberculosis meningitis. Ind J Tub I991, 38:99-102.

12. Kashyap RS, Kainthla RP, Mudaliar AV, Purohit HJ, Taori GM, Daginawala HF: Cerebrospinal fluid adenosine deaminase activity: A complimentary tool in the early diagnosis of tuberculous meningitis. Cerebrospinal Fluid Res 2006, 3:5.

13. Fresquet WC, Haas J, Wildemann B, Storch HB: Value of polymerase chain reaction (PCR) for diagnosis of tuberculoid meningitis. Nervenarzt 1998, 69:502-506.

14. Rafi W, Venkataswamy MM, Ravi V, Akepati C: A comparative evaluation of in-house PCR assays involving three mycobacterial DNA sequences, IS6III0, Rapid diagnosis of tuberculous meningitis: MPB-64 and 65 kDa antigen. J Neurol Sci 2006, 252:163-168.

15. Brisson NA, Aznar C: Diagnosis of tuberculosis by DNA amplification in clinical practice evaluation. Lancet 338:364-366.

16. Eisenach KD, Sifford MD, Cave MD, Bates JH, Crawford JT: Abstract Detection of Mycobacterium tuberculosis in sputum samples using a polymerase chain reaction. Am Rev Resp Dis 1991, I44(5): | I60-II63.
17. Guilhot C, Jackson M, Gicquel B: Mobile genetic elements and plasmids: tools for studies. In Mycobacteria, molecular biology and virulence Edited by: Ratledge C, Dale J. Oxford: Blackwell Science; 1999:17-37.

18. Kennedy DH, Fallon RJ: Tuberculous meningitis. JAMA 1979, 241:264-268.

19. Bhattacharya B, Karak K, Ghosal AG, Roy A, Das S, Dandapat P, Khetawat D, Mondal DK, Bhattacharya S, Chakrabarti S: Development of a new sensitive and efficient multiplex polymerase chain reaction (PCR) for identification and differentiation of different mycobacterial species. Trop Med Intl Heal 2003, 8(2): $|5|-\mid 57$

20. Rafi W, Venkataswamy MM, Nagarathna S, Satishchandra P, Akepati C: Role of an IS6 II 0 Uniplex PCR in the diagnosis of tuberculous meningitis: Experience at a tertiary Neurocentre. Int J Tub Lung Dis 2007, I I(2):209-2I4.

21. Ndugga LK, Cleeff MV, Juma E, Kimwomi J, Githui W, Oskam L, Schuitema A, Soolingen DV, Nganga L, Kibuga D, Odhiambo J, Klatser P: Comparison of PCR with the Routine Procedure for Diagnosis of Tuberculosis in a Population with High Prevalence of Tuberculosis and Human Immunodeficiency Virus. J Clin Microbiol 2004, 42:1012-10I5.

22. Clarridge JE, Shawar RM, Shinnick TM, Plikaytis BB: Large scale use of polymerase chain reaction for detection of Mycobacterium tuberculosis in a routine mycobacteriology laboratory. J Clin Microbiol 1993, 3 I:2049-2056.

23. Shankar P, Manjunath N, Mohan KK, Prasad K, Behari M, Shriniwas, Ahuja GK: Rapid diagnosis of tuberculous meningitis by polymerase chain reaction. Lancet 1991, 335:5-7.

24. Folgueria L, Delgado R, Palenque E, Noriega AR: Detection of Mycobacterium tuberculosis DNA in clinical samples by using simple lysis method and polymerase chain reaction. J Clin Microbiol 1993, 72:126-133.

25. Seth P, Ahuja GK, Bhanu NV, Behari M, Bhowmik S, Broor S, Dar L, Chakraborty M: Evaluation of polymerase chain reaction for rapid diagnosis of clinically suspected tuberculous meningitis. Tub Lung Dis 1996, 77:353-357.

26. Rafi A, Naghily B: Efficiency of polymerase chain reaction for the diagnosis of tuberculosis meningitis. Southeast Asian J Trop Med Pub Heal 2003, 34:357-360.

27. Nguyen LN, Kox LF, Pham LD, Kuijper S, Kolk AH: The potential contribution of the polymerase chain reaction to the diagnosis of tuberculosis meningitis. Arch Neurol 1996, 8:77।-776.

28. Ahuja GK, Mohan KK, Prasad K, Behari M: Diagnostic criteria for tuberculous meningitis and their validation. Tuber Lung Dis 1996, 75: I49-152.

29. Donald PR, Victor TC, Jordaan AM, Schoeman JF, Van Heldon PD: Polymerase chain reaction in the diagnosis of tuberculosis meningitis. Scand J Infect Dis 1993, 25:613-617.

30. Sumi MG, Mathai A, Reuben S, Sarda C, Radhakrishnan VV, Indulakshmi R, et al: A comparative evaluation of dot immunobinding assay (Dot-Iba) and polymerase chain reaction (PCR) for the laboratory diagnosis of tuberculous meningitis. Diagn Microbiol Infect Dis 2003, 35:372-377.

31. Soolingen DV, Hass PE, Hermans PW, Gronen PM, Embden JD: Comparison of various repetitive DNA elements as genetic markers for strain differentiation and epidemiology of Mycobacterium tuberculosis. J Clin Microbiol 1993, 31:1987-1995.

32. Das S, Paramasivan CN, Lowrie DB, Prabhakar R, Narayanan : IS6III0 restriction fragment length polymorphism typing of clinical isolates of Mycobacterium tuberculosis from patients with pulmonary tuberculosis in Madras, South India. Tuber Lung Dis 1995, 76:550-554.

33. Indulakshmi YK, Manju R, Kumar A, Sathish M: Implications of low frequency of IS II 160 in fingerprinting field isolates of Mycobacterium tuberculosis from Kerala, India. J Clin Microbiol 200I, 39:1683.

34. Dufaux MF, Vanfleteren B, Wit LD, Vincke JP, Van Vooren JP, Yates MD, Serruys E, Content J: Rapid detection of tuberculous and non-tuberculous mycobacteria by polymerase chain reaction amplification of a 162 bp DNA fragment from Antigen 85. Eur J Clin Microbiol Infect Dis 1992, I I:797-803.

35. Scarpellini P, Racca S, Clinque P, Delfanti F, Gianotti $n$, Terreni MR, Vago L, Lazzarini A: Nested polymerase chain reaction for diagnosis and monitoring treatment response in AIDS patients with tuberculous meningitis. AIDS 1995, I:885-890. 
36. Takahashi T, Nakayama T, Tamura M, Ogawa K, Tsuda H, Morita M, Hara M, Togo M, Shiota H, Suzuki Y, Minami M, Ishikawa H, Miki K, Shikata E, Takahashi S, Kuragano T, Matsumoto K, Sawada S, Mizutani $\mathrm{T}$ : Nested polymerase chain reaction for assessing the clinical course of tuberculous meningitis. Neurology 2005, 64:1789-1793.

37. Liu PY, Shi ZY, Lau Y], Hu BS: Rapid diagnosis of tuberculous meningitis by a simplified nested amplification protocol. Neurology 1994, 44: I |6I-II64.

38. Nguyen LN, Kox LF, Pham ID, Kuijper S, Kolk AH: The potential contribution of the polymerase chain reaction to the diagnosis of tuberculous meningitis. Arch Neurol 1996, 53:77I-776.

39. Marchandin H, Ventura V, Alonso JM, Van de Perre P: Mixed bacterial meningitis due to Streptococcus pneumoniae and Nesseria meningitides in an I8-month old child. J Clin Microbiol 2005, 43:1477-1479.

40. Huang PL, Yeh SH, Chiang CD: Detection of Mycobacterium tuberculosis in sputum by polymerase chain reaction. Chin Med J 1993, 52:332-337.

4I. Pai M, Flores LL, Pai N, Hubbard A, Riley LW, Colford JM: Diagnostic accuracy of nucleic acid amplification tests for tuberculous meningitis: a systematic review and meta-analysis. Lancet Infect Dis 2003, 3:633-643.

Publish with BioMed Central and every scientist can read your work free of charge

"BioMed Central will be the most significant development for disseminating the results of biomedical research in our lifetime. "

Sir Paul Nurse, Cancer Research UK

Your research papers will be:

- available free of charge to the entire biomedical community

- peer reviewed and published immediately upon acceptance

- cited in PubMed and archived on PubMed Central

- yours - you keep the copyright 